\title{
6 Market-led decline amidst intense politicization
}

\author{
Coal in the United States
}

\author{
Jiaqi Lu and Gregory Nemet
}

\section{Introduction}

Over the last two decades, the US coal industry has served as a high-profile battleground of polarized politics—while also steadily declining (Ballew et al., 2019, Skocpol and Hertel-Fernandez, 2016). Central to this decline and coal's influence has been a change in expectations. The 2010-2020 period saw the outlook for US coal change dramatically - from the one of new plant construction and mine expansions that would continue to boost the industry for decades, to the one of early plant retirements and mine closures that halved coal's contribution to energy supply. Moreover, government forecasts and elicitations from our interviewees are in consensus that coal will continue to decline through the 2020s, with the only disagreement on the extent. During this process, coal interests have been fought to preserve their industry by exploiting the institutional weakness and utilizing the widening divide between conservative and progressive politics. Conservative politicians, funded by coal interest groups, attracted support from coal miners by providing a voice to their economic hardship, as well as the identity and culture of the coal mining communities. Pro-climate NGOs have also tried to help local coal communities manage the transition from coal to relieve the pain associated with coal's decline in the notable absence of transition aid from states and the federal government. This chapter will show that the decline of coal in the United States is mainly driven by inexpensive alternative energy sources and a regulatory system whose primary objective is minimizing electricity costs. The politicization of coal, on the other hand, is shaped by a group of industrial, social, and political actors with different objectives, highly embedded in the United States's distinct socioeconomic and political context.

Existing scholarship on the political economy of coal in the United States has shown that technological change, business interests (Stokes, 2020, Skocpol and Hertel-Fernandez, 2016, Downie, 2017, Berardo and Holm, 2018), and political movements (Brulle, 2018, 2019, Stokes, 2016, Breetz et al., 2018, Farrell, 2016) have been influential, not just on the industry but also on US energy and climate policy more broadly. Despite the extensive literature on this topic, we still do not have a comprehensive answer to the question of why the coal industry has failed to resist or even slow down its rapid decline despite having enormous 
political support? An abundance of studies provides answers related to the development and impacts of environmental regulations (Layzer, 2012, Davis et al., 2016), challenges from alternative fuels (Stokes and Breetz, 2018), interest group influence (Stokes, 2020), and public opinions on non-carbon energy and climate change (Karol, 2019, Ballew et al., 2019, Ansolabehere and Konisky, 2009, 2014). These studies provide important glimpses on particular aspects. Our article contributes to this literature by providing a comprehensive assessment that documents the institutional context, the divided political environment, relevant stakeholders, social and political actors, as well as public debates on climate issues and the logic behind the political rhetoric.

Building on the theoretical framework proposed in Chapter 1, we consider energy and climate policy to be shaped by multiple social and political actors with diverse objectives, each operating within an idiosyncratic country context (Jakob et al., 2019). We identify the competing objectives, stakeholders, and contextual factors that explain why coal has dominated political debates despite unfavorable economics and a rapidly shrinking share in the energy mix. We draw on 20 semi-structured expert interviews (conducted face-to-face, over the phone, or over Zoom) with representatives who shape climate and energy policies in the United States, including regulators and legislators at the state and federal level, utilities, industry, civil society, as well as nongovernmental organizations (see Table A6.1). We identify key stakeholders for interview using snowball sampling method that relies on expert referrals. For details of the semi-structured interview questions, please see the interview guideline in the Online Appendix. The extensive data collected in expert interviews that shed light on otherwise hidden interrelations between electricity markets and politics could not only explain the decline of coal but also help us understand the political implications for deep decarbonization beyond coal. Based on the interview data, we identified a group of actors and contextual factors that influence energy and climate policies in the United States. These actors include federal and state regulators and politicians (national and regional policy makers and political actors), utilities and the coal mining industry (public and private economic actors), and domestic civil society (societal actors). We also identify four high-level objectives: affordability, reliability, climate change mitigation, and employment.

\section{Country context}

US electricity supply has changed dramatically over the past decade and a half. The share of electricity from coal-fired power plants decreased from 50\% in 2003 to $23 \%$ in 2019. This section provides an overview of coal energy in the United States, focusing on the technological and economic environment. The major contextual difference between the United States and many other cases in this book is that coal is currently in a sharp decline; plants are retiring, and no new construction has occurred in the past ten years. Coal has been driven out of the market mainly by inexpensive natural gas, wind, and solar energy. 
Changes in these competing technologies are more important than policies and the efforts of interest groups. Electric utilities, the primary consumers of coal, are actively phasing out coal for economic reasons, accommodate socially responsible investing, respond to their customers' preferences for clean power, and retain their social license to operate. From a policy perspective, these developments are driven not by any concrete federal climate regulations, but by the anticipation of possible legislation in the future.

\section{Market conditions and the decline of coal}

Coal consumption in the United States has declined from its peak in 2007 of 1 billion tons to 535 million tons (mt) in 2019. As of 2019, the electricity sector accounts for nearly $92 \%$ of domestic coal consumption. With total US electricity consumption remaining mostly constant since 2005 , steam coal consumption was nearly cut in half from its 2007 level. The remaining $8 \%$ is used by the manufacturing industry, including coking, food, paper, steel, and other industrial sectors. Industrial coal consumption has also declined, from $75 \mathrm{mt}$ in 2007 to $38 \mathrm{mt}$ in 2019 (EIA, 2020a).

The main driver behind the decline of coal in the power sector is technological change that has made electricity from natural gas, wind, and solar energy much less expensive than in the past. As shown in Figure 6.1, the levelized cost of electricity (LCOE) from coal has been stable over the past decade, while the cost of cleaner alternatives-natural gas, wind, and

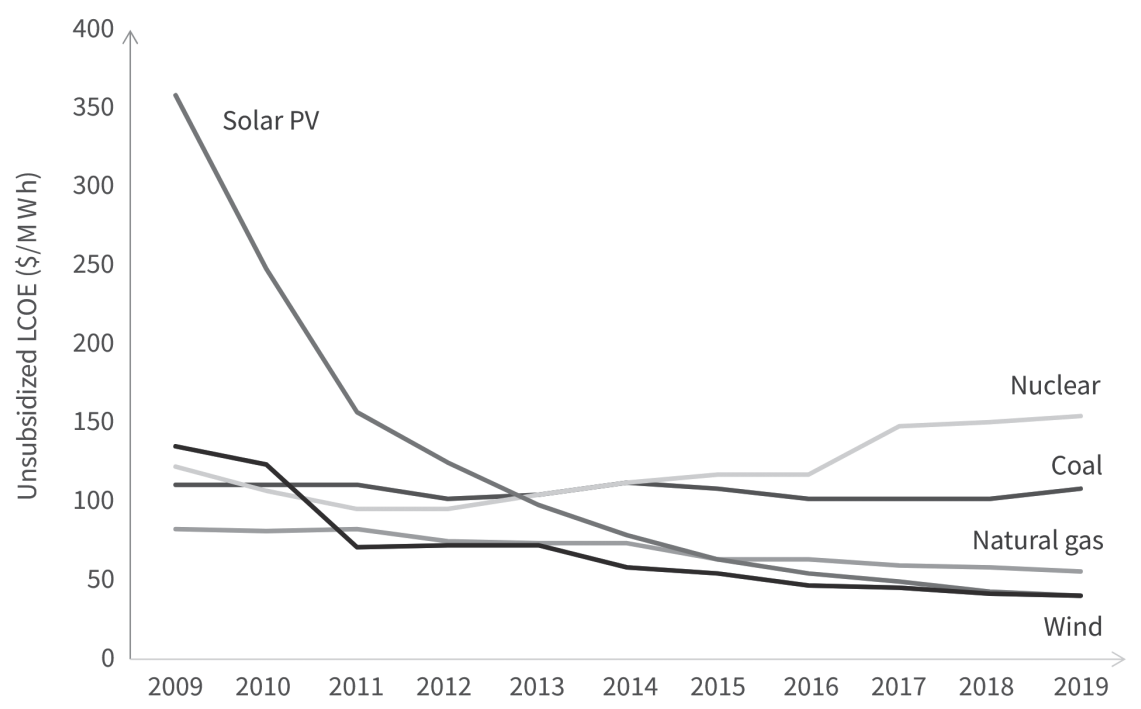

Figure 6.1 Unsubsidized levelized cost of electricity for US power generation 2009-2019.

Source: Lazard's Levelized Cost of Energy Analysis. 
solar-has all decreased. In particular, the levelized cost of wind and solar have dropped from more than $\$ 145$ per $\mathrm{MWh}$ and $\$ 360$ per MWh in 2009 to $\$ 45$ per MWh in 2019 (LAZARD, 2020). The levelized cost of coal-fired power plants is roughly twice that of a natural gas plant, which is also smaller, more efficient, more flexible, and thus more compatible with intermittent renewable energy in its ability to ramp up and down quickly. As coal has become relatively more expensive, the average capacity factor of coal power plants has decreased from 67\% in 2010 to $40 \%$ in 2020 (EIA, 2021b), making coal electricity more expensive to produce as fixed costs must now be spread over fewer electricity outputs.

The competitive disadvantage of coal has changed utilities' planning for new electricity generation projects. Utilities, and independent power producers who sell electricity to utilities, choose natural gas, wind, and solar to meet new electricity demand. Most dramatically, utilities are shutting down existing coal plants. Some of these are quite old plants, but others are being shut down decades before their normally expected retirement dates.

The changing prospects for coal come on top of a decades-long lack of new investment in coal as US power infrastructure aged. Between 2010 and 2018, the average age of coal fleets in the United States is 42 years old, while the average retirement age is around 55 years old (EIA, 2019). Many coal power plants have been run up to 20 years beyond their designed retirement age. Over the same period, the electricity sector retired more than $89 \mathrm{GW}$ of coal-fired capacity from its peak in 2011 to 229 GW in 2019, replacing 546 coal units with mostly natural gas-fired combined-cycle plants, solar, and wind energy. Utilities and independent power generators plan to retire an additional 22 GW of coal capacity by 2030, as is shown in Figure 6.2. This trend has accelerated since the Trump administration took office in 2017. From 2016 to 2019, the annual retired capacity has nearly tripled, while the average retirement age has decreased by roughly ten years over the same period. This means younger and bigger coal facilities have been retired despite changes in the political environment.

The rapidly changing energy market can be best illustrated by the Energy Information Administration (EIA) annual energy outlook. The outlook of coal production reflects the changing market prospects of coal over the last 15 years. As shown in Figure 6.3, predicted coal production in 2030 has decreased from 1,544 $\mathrm{mt}$ in the 2006 energy forecast to $484 \mathrm{mt}$ in the 2020 forecast. The overall trend of EIA forecasts shifted from growing in 20062012 to relatively stable in 2013-2015, and to a significant decline in 20162020. To provide a more independent view about the prospects for coal, we asked the expert interviewees for their predictions of the share of electricity production from coal in 2030, and then compared these predictions with historical and forecast data from the EIA. Figure 6.3 shows that experts' market expectations of coal are clearly more pessimistic than that of the federal government. Most interviewees contend that coal companies also share their pessimistic view about the future of the industry. These changes regarding 

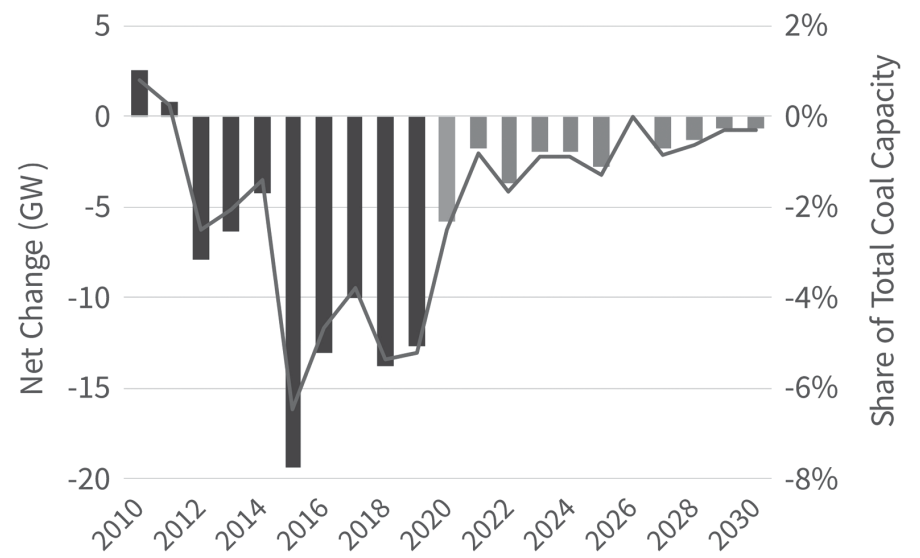

Figure 6.2 US coal power plant retirements 2010-2030.

Source: US Energy Information Administration, Annual Electric Generator Report and Preliminary Monthly Electric Generator Inventory.

market expectations play an important role in understanding the actions of firms and interest groups in the US coal industry.

\section{Coal industry response to the decline}

The coal mining and utility industry has been slow to respond to what has turned out to be a dramatic change. The changing market expectations largely determine the responses of the coal mining and coal power industry. Figure 6.4 demonstrates that expectations about the future of coal began to shift in 2007 , the first year of less than $1 \%$ annual expected growth after a decade of expectations of $1 \%-2 \%$ annual growth. 2010 was the first year in which coal production was expected to decline. Expectations of a gradual decline (1\%$2 \%$ /year) began to accelerate in 2015 ; by 2020 , the outlook for the next couple of years was sharp declines, over $10 \%$ per year. The government forecasts in 2019 and 2020 became aligned with expert interview responses in 2020, which showed median expectations of a 6\% annual decline through 2030.

In response to the shrinking domestic demand, the coal mining industry has been adopting several strategies, including diversifying business structure and exploring opportunities in the steel and coal-chemical industry [sn3]. ${ }^{1}$ Additionally, many coal mining companies are trying to expand the market for exports, which identified many interviewees as the "key strategy that keeps them alive" [pr1, pn1, sn1, sn3, r2, b1, sn5, pn2, pn3, b2]. However, the prospect of coal export is limited because of strong competition and high uncertainty associated with the Asia market (see a more detailed discussion about the export market in the Online Appendix). Domestically, US coal 


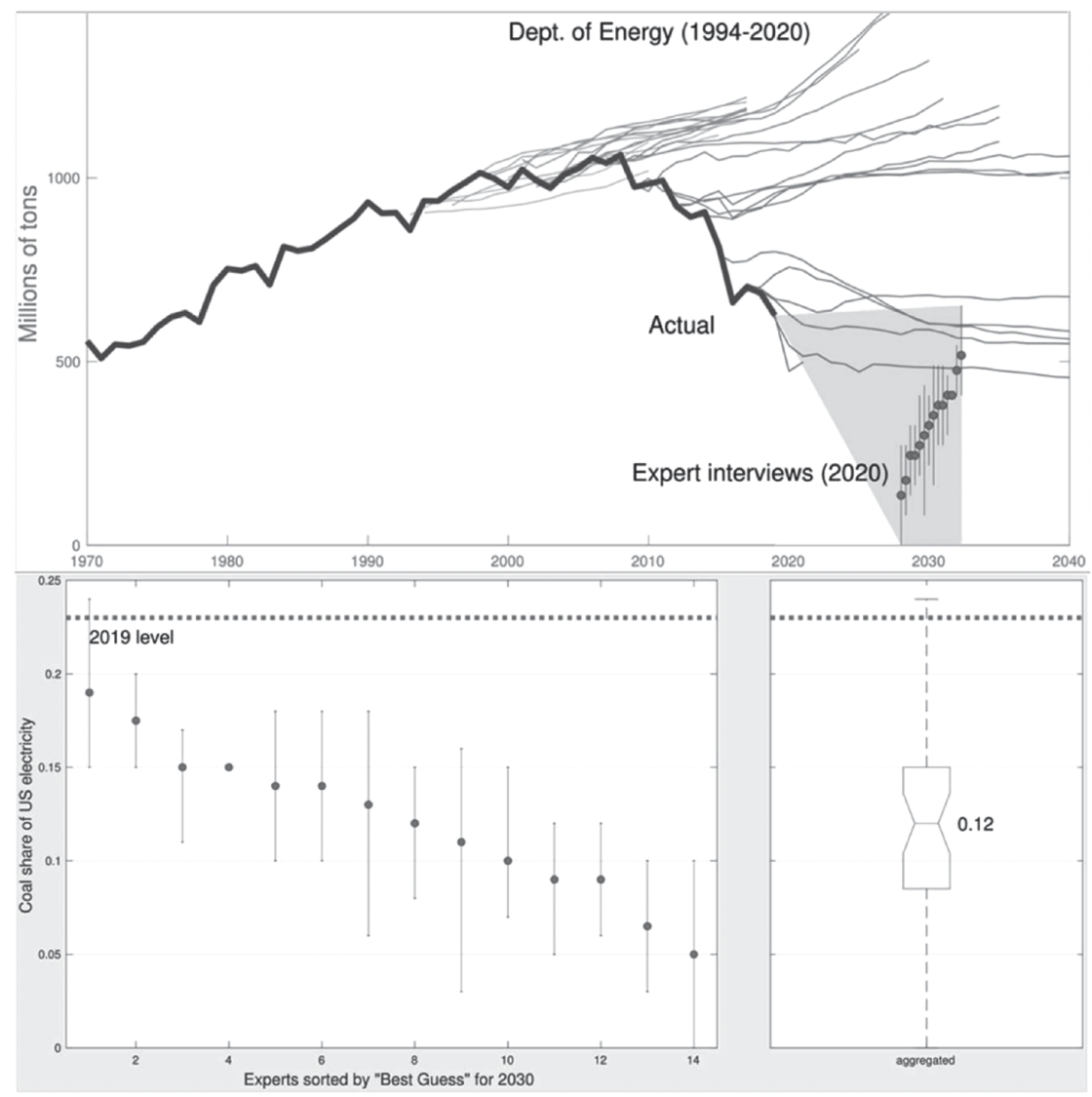

Figure 6.3 Expert assessment and EIA outlook of coal production in the United States. Note:The most recent EIA forecast is "short term," that is, for 2020 and 2021, published on May 12, 2020, and accounts for the COVID-19 recession.

Source: EIA Annual Energy Review 2011, Annual Coal Report, Annual Energy Outlooks 2006-2020.

exports also face regulatory uncertainty, lack of infrastructure, and political challenges from environmental groups. Experts pointed out that a future democratic administration could easily constrain the economics of export by imposing more regulations on mining, transportation, and storage [pn1]. More importantly, coal export to the Asian market has been limited by the port capacity on the West Coast [sn4, sr2, pn2, pn3, b2]. As of 2019, there are only three small export terminals with limited export capacity located on the Californian coast. Although the coal industry has been urging port capacity expansion, such effort has faced strong pushbacks from local communities and city governments [sr2]. 


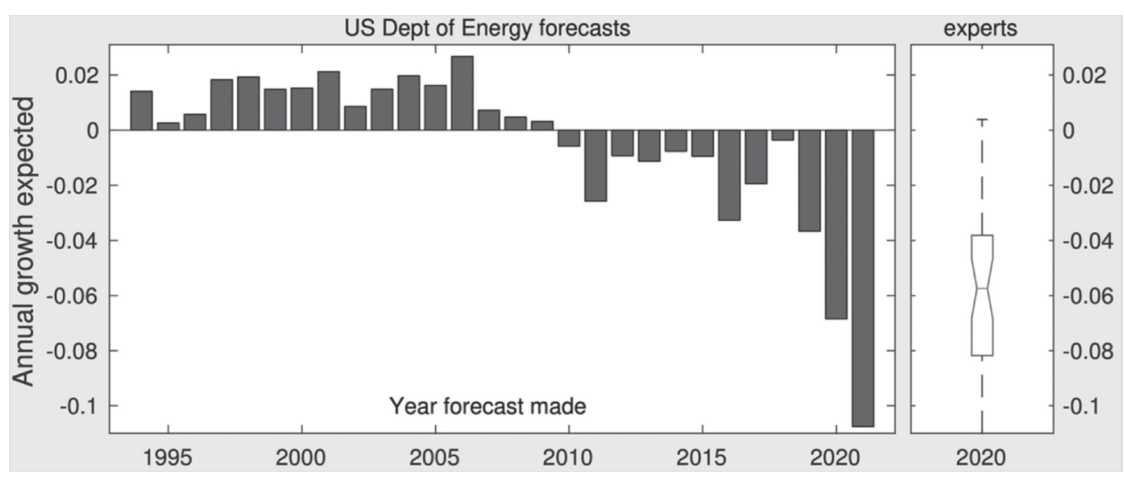

Figure 6.4 Growth rates in US coal production implied by government and expert forecasts of future coal production.

Note: Growth rates are calculated over the first five years of the forecast. Experts were interviewed in early 2020 .

\section{Policy objectives}

The electricity sector in the United States is highly regulated and is still dominated by local monopolies, despite efforts to introduce competition over the past three decades. At the federal level, energy and electricity are under the regulation of the Department of Energy (DOE) and the Federal Energy Regulatory Commission (FERC), and environmental issues are under the jurisdiction of the Environmental Protection Agency (EPA). Public Utility Commissions (PUC) at the state level regulate electricity providers, such as utilities and independent power producers. Although their regulatory boundary varies from state to state, the most important functions of PUCs are rate setting, generation, transmission project approval, and reviewing business decisions faced by public utilities.

We group actors' objectives into four high-level strategic objectives of energy policy: affordability, reliability, climate change mitigation, and employment. In particular, affordability was highlighted by interviewees as the most important objective that shapes energy policies. Indeed, PUCs typically mandate utilities provide electricity at just and reasonable rates. Climate change mitigation, regarding both environmental and climate impact, was also identified by most experts. Although security is a major focus in the political discourse, it did not stand out as a crucial concern in our interviews. Perhaps the reason that security did not emerge in interviews is that coal, natural gas, wind, and solar are abundant domestically in the United States, so neither coal nor its competitors can make credible claims of being preferable on energy security grounds. Finally, employment and economic development for local coal communities stand out as major concerns for regional societal actors and politicians. Table 6.1 presents an overview of objectives, relevant actors, and the contextual factors shaping energy policy making in the United States. 
Table 6.1 Objectives, actors, and cross cutting contextual factors of US energy policy

\begin{tabular}{ll}
\hline Objectives of energy policy & Most relevant actors \\
\hline $\begin{array}{l}\text { Affordability } \\
\text { Reliability and security }\end{array}$ & FERC, PUC, utilities \\
$\begin{array}{l}\text { Climate change mitigation } \\
\text { Employment }\end{array}$ & DOE, FERC, coal mining industry \\
& State-level legislature, EPA, NGOs \\
$\begin{array}{l}\text { Local coal community, local government, } \\
\text { NGoxpenting contextual factors }\end{array}$ & NGoliticians \\
$\begin{array}{l}\text { Polarized political environment } \\
\text { Organized interest groups }\end{array}$ & \\
Lack of government supports for job creation in coal communities \\
\hline
\end{tabular}

\section{Affordability}

The US federal government has been devoted to lowering energy prices and has branded cheap energy as one of the competitive advantages for US businesses. Over the past decades, the United States has had one of the lowest electricity rate among advanced economies. The rate for the industrial sector is even lower than that in many developing countries, such as China. In 2019, the residential, commercial, and industrial sectors accounted for $37 \%, 36 \%$, and $26 \%$, respectively, of the total US electricity consumption (EIA, 2020b). On top of that, some states and the federal government often provide various energy assistance or efficiency programs for low-income families, further improving energy equity and affordability. Many states also intend to minimize the electricity rate to attract investment, especially for the manufacturing industry. Therefore, minimizing electricity rates for local consumers is the most important regulatory objective for the PUCs and a critical principle of the wholesale market designed by the FERC. The average electricity rate varies from state to state (ranging from 7.77 cent/kWh in Louisiana to 29.04 cent/kWh in Hawaii, averaging at 10.80 cent/ $\mathrm{kWh})$. In general, it is highest for the residential sector (13.36 cent/kWh), and the lowest for the industrial sector $(6.91 \mathrm{cent} / \mathrm{kWh})$, with the rates for the commercial sector $(10.88$ cent/kWh) in between (EIA, 2021a).

Electricity market deregulation has also contributed to this objective. Traditionally, the US electricity markets have been strictly regulated, where a public utility serves as a natural monopoly in a given region. In regulated markets, utilities hold control over all electricity services across much of the country, from electricity generation, transmission, distribution, all the way down to customer metering. The PUC in charge of rate setting and project approval aims to minimize electricity rates for the local customer while ensuring a fixed profit margined for investors. Following the enactment of the National Energy Policy Act of 1992, the federal government started to allow power producers to compete for selling electricity to utilities. In the late 1990s, the FERC issued three orders to establish several regional transmission operators (RTOs) and 
independent system operators (ISOs) across the country, ensuring utilities' fair access to the grid. In the 2000s, several large states, including California, Texas, and New York, initiated the deregulation reforms. Today, a total of 15 states have initiated reforms with different levels of deregulation and different emphases. The most common feature for all these reforms is to involve competition in both generation and service provision to lower prices and improve services. A significant consequence of such reforms has been the rise of investor-owned utilities, which issue stock traded on stock exchanges and with a fiduciary responsibility to shareholders to maximize shareholder value.

Under the price pressure from regulators and market competition, coal technologies, such as carbon capture and storage, once seemed profitable have become too expensive (see detailed discussion about CCS technology in the Online Appendix). Utilities, which consume more than $90 \%$ of US coal, have no choice but to build the most inexpensive power plants in order to minimize the electricity bill for customers. As the costs of natural gas and renewables have become much lower than that of coal, it is in utilities' best interest to choose those technologies instead of coal to keep rates low and fair, even without additional climate regulation. Although the affordability objective is picked up by societal actors and national/regional policy makers who are pro-coal, to some extents, their narrative contradicts their goal, because using coal for electricity production would result in higher energy bill in most parts of the United States.

\section{Reliability and security}

As alternative sources obtain increasing market advantage over coal, coal-heavy utilities and the coal mining industry start to stress grid reliability and energy security as their core competitiveness [pr1, b1]. Experts who are familiar with energy lobbying described how coal lobbying groups have switched from claiming "cheap and widely available" to "a reliable and secure energy source" as the main selling point for coal power [pr1].

The concept of grid reliability, also known as system security, is built on the idea of baseload power sources for providing stability and resilience to the electric system during times of grid constraint. Coal advocates argue that coal-fired electricity can provide critical capacities to stabilize the grid and electricity prices in the wholesale market, especially during winter. Hence, they claim that coal-fired power plants deserve additional service fees to help them stay in business [pr1, sn3, pn3]. For example, America's Power (2020), an interest group that advocates on behalf of coal-power plants, indicates that the acceleration of coal retirement could lead to a $35 \%$ or US\$29 billion increase in electricity bill due to extreme cold weather across multiple markets by 2024 , while keeping those coal units could cut down such cost by over 93\%. In 2018, FirstEnergy Solutions, a utility company that owns coal and nuclear power plants, asked the DOE to invoke its emergency power under Section 202(c) of the Federal Power Act to provide cost recovery to coal and nuclear plants for the next four years. This request was immediately rejected because the DOE has never issued an emergency order for economic reasons (Walton and Bade, 
2018). Granting coal facilities that kind of bailout might have provoked waves of lawsuits from environmental groups and the renewable industry.

Unsurprisingly, the security narrative resonates well with the policy agenda of the Trump administration. Since Trump took office in 2017, the DOE has been invoking electricity market regulations that favor coal fleets in the name of system security, and even considered invoking executive power under the 1950 Defense Production Act (DPA) to boost coal-fired electricity production (John, 2018). However, there are only limited measures that the executive branch can use on security grounds. In late 2017, Secretary of Energy Rick Perry filed a Notice of Proposed Rulemaking that intended to provide bailouts for coal and nuclear power plants that maintain 90 days of fuel supply, citing the importance of grid resilience due to natural gas and renewable penetration, and unfair wholesale market design in favor of them (FERC, 2018). In 2018, this proposal was unanimously rejected by the FERC, despite the Commission's consisting of two Democrats and three Republicans, four of whom were appointed by President Trump. The FERC ruled that the DOE failed to provide evidence to support their claims, citing reports from RTOs/ISOs that show no security concern due to coal plant retirements (FERC, 2018).

\section{Climate change mitigation}

The third high-level energy policy objective concerns environmental and climate challenges. For decades, various social actors, including progressive think tanks, NGOs, and activists, have been pushing climate and environmental legislation at the state and the federal levels. More recently, pro-environment and pro-climate change grassroots movements have formed a strong anti-coal coalition, which imposes public pressure on utilities and banks to divest from coal. Experts express that such public pressure helps motivates utilities to choose natural gas or renewables over coal facilities out of public image concerns [sr2]. Many banks and institutional investors across the country have also committed to divestment. The divestment movement takes many forms. For instance, socially responsible investing (SRI), an investment strategy championed by investment banks such as BlackRock, ${ }^{2}$ encourages investor-owned utilities to retire coal to placate shareholder activist groups. Furthermore, over the last few years, students have become a new powerful force in pro-climate change movements. Famous youth-led climate strikes, such as the Youth Climate Movement, have spread across the United States, calling the county, state, and federal government to take immediate climate actions and declare a climate emergency.

\section{Federal-level policies}

Even though an overwhelming majority of Americans support more progressive federal policies to address climate change (Tyson and Kennedy, 2020), climate legislation remains stagnated in the US Congress. In the early 1970s, protecting environmental quality had received considerable bipartisan support as much of the nation's landmark environmental legislation, most importantly, the Clean 
Air Act, was passed during the Nixon administration. However, since the late 1970s, the United States has experienced serious political polarization at both the state and the federal levels (Caughey et al., 2017, Grumbach, 2018, Lowry, 2008). Such division along partisan lines is also found on environmental issues. As the memory of the oil crisis in the 1970s faded away, energy policy became increasingly aligned with environmental policy (Lowry, 2008). The bipartisan support for energy and environmental policies decreased in the polarized political environment. When climate change first entered the sight of the general public in the late 1980s and early 1990s, the idea of shifting away from fossil fuels was already highly political. As a result, energy policies have become regulatory, and the prominence of partisanship on the issue increased over time. Scholars have found sharp polarization of conservative-liberal opinion about energy and environmental matters after the Cold War (McCright et al., 2014).

Highly organized fossil fuel interest groups contributed to the political polarization on climate change at both the state and the federal levels (Grumbach, 2019, Stokes and Breetz, 2018, Jacques et al., 2008). In the past 13 election cycles, the coal mining industry has been the largest source of campaign finance within the mining industry, with $88 \%$ of those going to Republican candidates. ${ }^{3}$ In the early 2000 s, the coal interest groups wield significant influence in Washington D.C. As one interviewee recalled:

We [Senate democrats] tried to get [environmental/climate legislations] enacted during the Bush administration ... we were very close to a deal in 2001, so there would have been limits on the utility industry ... but the Coal Industry and the Mining Association got to theVice President's office, and they killed that bill. And they also got the President (Bush) to reverse his pledge during the campaign to control carbon dioxide from power plants [pn1].

Coal interest groups found their natural allies in the conservative movement. Conservative think tanks, backed by the fossil fuel industry and the auto industry, play a major role in developing the rhetoric and talking points to support a position of climate denial (McCright and Dunlap, 2000, Boussalis and Coan, 2016).

During the Obama administration, environmental regulation was the primary policy tool to reduce coal consumption. The most consequential regulations were the Mercury and Air Toxics Standards (MATS) that targets mercury emissions and the Cooling Water Intake Rule that manages wastewater from power plants [pr2, sn3, r2, b2]. In particular, the MATS regulation, proposed in 2008-2009 and passed in 2012, imposed high costs ( $+100 \%$ operating costs) on old coal power plants, incentivizing many utilities to switch to gas rather than investing in pollution control equipment for coal units [r2, pr3, b3]. Experts suggest that the MATS alone contributed to roughly $5 \%-10 \%$ of total coal retirements to date [r2]. The Clean Power Plan (CPP), the Obama administration's centerpiece energy and climate policy, although highly celebrated, was never officially implemented, in part due to opposition from conservative politicians and procoal actors (see the online Appendix for more detailed discussion). 
Under the Trump Administration, the EPA has been rolling back environmental and climate regulations that constrain the coal mining and utility industry. It is commonly believed that conservative politicians and coal interest groups are colluding with each other to bring coal back by ending "the war on coal." Yet, the coal mining industry has long realized that regulatory relief could not reverse market force and revive coal [pn3]. As one interviewee put it:

Politicians argue that [rolling back regulations can revive coal] ... They [coal companies] do not argue that ... most of them are just getting out of the business, they're selling assets or they're going bankrupt ... Bob Murray ${ }^{4}$ is sort of the case in point. He has asked for an enormous bailout in the stimulus package. And he has repeatedly asked for government bailouts because it's the only way that he can remain economic ... What he says in public is different than the things he asked for, he doesn't ask for regulatory relief. He asked for cash [pn3].

The Trump EPA also repealed the CPP and replaced it with a much weaker Affordable Clean Energy (ACE) rule, which would lower power sector carbon emissions by $11 \mathrm{mt}$ by 2030, or between $0.7 \%$ and $1.5 \%$ from its 2005 level. Even though the high-ranking Trump appointees in the DOE and the EPA often take a hostile position toward climate change, mid-level and lower level bureaucrats were still taking the issue seriously and continued to prepare for future climate actions [pn4]. Under the Biden Administration, the federal government was able to reinstate and strengthen Obama-era regulations. President Biden has brought the United States back to the Paris Agreement and announced to use new executive orders to tackle climate change (The White House, 2021). However, it is unlikely a future Republican administration would continue to support these climate actions without new legislation from Congress.

\section{State-level policies}

With the US Congress in gridlock, ${ }^{5}$ many energy and climate policies that matter the most for the future of coal consumption are implemented by states [r1, r3, sn4]. When the Trump Administration withdrew from the Paris Agreement in 2017, some state governments led open protests against the federal government. Since 2016, a total of 34 states - including some Republican states - have released or updated their state-level climate action plans, which generally include greenhouse gas mitigation targets and detailed policy tools to meet those goals. ${ }^{6}$ Nine states, together representing $40 \%$ of US greenhouse gas emissions, have passed laws mandating 100\% carbon-free electricity by 2050 (Podesta et al., 2019).

One of the most important state policy tools to date for climate mitigation is the Renewable Portfolio Standard (RPS), which requires a specified percentage of electricity from local utilities generated by renewable sources. From the late 1990 s to the early 2000s, several states at the demand centers, 
including California, Texas, and some New England states, led the effort to put the RPS into state law. As of 2020, a total of 38 states have implemented either a renewables mandate (31 states) or a volunteer target ( 7 states), with wide variation in terms of compliance options (NCSL, 2020).

With the rapid growth of RPS popularity, the slow response of the coal industry in the 2000s and intense lobbying in the 2010s reflect substantial changes in market expectations. When the RPS was first introduced, the coal industry fails to anticipate that it could help make the renewables so much more competitive, and so did not lobby against its implementation (Stokes, 2020). However, as market conditions changed dramatically, coal interest groups across the country mobilized to prevent further state legislation. As a result, all mandated RPS were written into law before 2008. Since then, utilities and the coal mining industry have successfully blocked RPS in the states that did not yet have them and repealed WestVirginia's RPS, which was passed in 2009. The latest attempt to strip the RPS is the 2019 Ohio House Bill 6, which replaces the RPS requirement of $12.5 \%$ in 2027 to $8.5 \%$ by 2026 , along with other procoal articles (The Ohio Legislature, 2019). A serious corruption scandal that involved FirstEnergy Corp. and Speaker of the Ohio House of Representatives was discovered to be behind the passing of this legislation (Wamsley, 2020). This incident once again suggests that the legislature and regulators can be easily captured by coal interest groups.

Renewable energy interest groups also have growing political influence in liberal states such as California and Washington. The renewable energy industry coordinated with environmental groups to advocate for investment rebates and higher RPS targets at the state level and tax credits at the federal level. Unlike the fossil fuel lobbying associations that are concentrated, the number of renewable lobbying associations is relatively high, partially due to the distributed nature of the industry (Kang, 2016), making it difficult to funnel resources and political influence to clean energy producers. Despite having the fossil fuel lobby as the common enemy, surprisingly, renewable interest groups also devote resources to lobbying against nuclear power. As the competition between different lowcarbon energy intensifies interest group politics might increase the difficulty and cost of deep decarbonization (Sivaram, 2018).

\section{Employment and regional economic development}

Coal miners' associations, such as the United Mine Workers of America, are important pro-coal social actors in the United States. These organizations often exert significant POLITICAL influence on legislators, even though the coal industry only represents a small share of the economy. Coal mining and coal electric generation employ a total of 139,785 workers across the country in 2018, with the coal mining and utility generation segment comprising 54\% and $17 \%$ of them, respectively (Ellis and Fazeli, 2019). In particular, coal mining jobs have decreased from 89,400 at the beginning of 2012 to less than 42,000 as of April 2020 (USBLS, 2020), which is also down from an all-time high of 1 million in 1920. Regarding the demographics of the work force, over $90 \%$ of 
the coal mining labor forces are white, which is significantly higher than that of the national workforce average of 78\% (Ellis and Fazeli, 2019).

As of 2015, only 26 counties across ten states are considered coal mining dependent under the Department of Agriculture's Economic Research Service (Morris et al., 2019). Many of these counties depend entirely on coal for the local economy, jobs, and tax revenue used for schools and other social services. In the existing market environment, coal communities across the country have been struggling. These communities have suffered from job loss, environmental degradation, decreasing new investment, limited alternative job opportunities, as well as shrinking local government budget due to the decline of coal, while state and the federal governments have provided very limited support [sr1]. Interviewees pointed out that many coal workers are reluctant to relocate to other places where jobs are growing [sr1, sr2]. Whereas the communities in Wyoming are in a denial stage, local communities in the Appalachia region, which have been dealing with the decline of coal for a much more extended period (since the 1920s) [sr1]. With the help from NGOs, such as the Beyond Coal Campaign of the Sierra Club, some communities have initiated various projects to explore alternative job opportunities and economic development paths [sr1, sr2]. Under the Biden Administration, the federal government incorporates "revitalize coal communities" as one of the targets in the executive order for tackling climate, though the effectiveness of such action remains an open question.

Job losses associated with the decline of coal drive local political support for the Republican Party (Egli et al., 2020). The Trump campaign has been trying to appeal to voters in coal-rich states [r1]. Trump won 19 of the 24 coal producing states in the 2016 election, 17 in 2020. President Trump repeatedly endorsed coal and coal mining companies, calling coal "beautiful" and "clean", and promised communities to bring their coal jobs back. As a useful campaign strategy, Trump associated coal jobs with conservative narratives of the mining industry, which romanticize miners as brave and hardworking men who risk their lives in the mines for their family and the American Dream (Hermwille and Sanderink, 2019, Carley et al., 2018). These narratives also appealed to average Republican voters, who believe in the concept of small government, anti-regulation, and traditional conservative values. Despite Trump's failure to bring back coal, residents of the coal communities expressed appreciation for the political attention even though many of them have well acknowledged the inevitable decline of coal [sr1, pn2, b2].

\section{Conclusions}

Based on quantitative data and insights from expert interviews, this analysis provides an overview of the recent evolution of the US coal industry. We identify affordability as the most widely embraced objective within US energy policy making. This objective of minimizing energy costs, combined with technological change in natural gas, wind, and solar, elevated market forces against coal to a prominent position, which lobbying, court cases, and President Trump 
could not overcome. Under this growing market pressure, the coal mining industry is clearly in retreat, so much so that the vast majority of coal companies have accepted their diminishing role in the energy system. The defeat of the $C P P$ was the last successful mobilization by the coal interest groups, with conservative movements and anti-climate groups being the main forces behind it. However, even this success did little to help the industry. Indeed, emissions are on pace to meet the $C P P$ target just due to coal losing market share to gas and renewables. While the Trump administration has abolished domestic and international climate policies, it failed to revive the market prospects for coal. The pro-coal policies implemented by the Trump administration have been ineffective and have no tangible impact on the energy market nor - as both our interviewees and the US EIA's forecasts show - have they done anything to improve the future of the industry. Many interviewees point out that coal companies have abandoned their strategies to preserve the market share in the US electricity sector. Instead, they employed different business plans to restructure their companies, exploring potential foreign export markets and the opportunities in metallurgical coal, and seeking government payouts in exchange for shutting down their companies.

To date, the United States is on its way to meet its former climate mitigation pledge under the Paris Agreement. Carbon emissions are expected to decrease by $35 \%$ by 2030 even without any federal intervention. Although the United States has cultivated this remarkable decarbonization progress by replacing coal with shale-based natural gas, from a supply-side perspective, fracking additional natural gas is no more than to double-down on the fossil-fuel-fired development path. Even if the United States manages to power its entire economy with natural gas, as a hydrocarbon fuel, natural gas can only provide limited mitigation benefits because targets will soon need to approach zero and because methane leakage from gas infrastructure is coming under increasing scrutiny. Although frequently touted as a bridge fuel, in the United States it has seldom been asked where this bridge will lead, how long it will exist, and to what extent it will compete and delay the expansion of renewables.

It is possible that the US power sector will become increasingly dependent on natural gas for the next 20-30 years. If so, natural gas interest groups would become more deeply embedded in the political and socioeconomic contextin the same way that the coal industry has for the past three decades. If the polarized politics regarding renewable and climate policies were to continue, the natural gas industry would only get increasingly hostile toward renewables, potentially hindering further decarbonization. The political economy of climate policy in the United States will likely continue to be fraught despite the demise of the coal industry.

\section{Appendix}

This chapter contains supplementary online material at www.mcc-berlin.net/ $\mathrm{pecoal} / \mathrm{ch} 06$. 


\section{Notes}

1 For instance, Arch Coal sold some of their thermal coal mines in 2019 and expand metallurgical coal production. In 2020, the company renamed its name to Arch Resource, Inc.

2 BlackRock, the world's largest asset management company, announced that they are divesting from companies driving more than $25 \%$ of their revenue from thermal coal.

3 Data from opensecrets.org.

4 CEO of Murray Energy, a private-owned coal mining company. He praised Precedent Trump for his pro-coal rhetoric and regulatory rollback on many media platforms, attracting nation-wide attention.

5 In the United States, the political cleavage between Democrat and Republican politicians on climate- and energy-related issues is salient, making it impossible to pass any national level climate or renewable energy legislation. Senate Republicans can block any climate or clean energy legislation with just 41 votes using filibuster. Senate Republican leader, Mitch McConnell, has repeatedly stated that the Senate would not put any climate legislation to a vote under his watch.

6 Data from the Center for Climate and Energy Solutions. www.c2es.org/document/ climate-action-plans/.

\section{References}

America's Power (2020). National Lab Study Shows Higher Energy Prices Due to Coal Retirements. [Online]. Available: www.americaspower.org/national-lab-study-showshigher-energy-prices-due-to-coal-retirements/.

Ansolabehere, S. \& Konisky, D. M. (2009). Public attitudes toward construction of new power plants. Public Opinion Quarterly, 73, 566-577.

Ansolabehere, S. \& Konisky, D. M. (2014). Cheap and Clean: How Americans Think About Energy in the Age of Global Warming, MIT Press.

Ballew, M. T., Leiserowitz, A., Roser-Renouf, C., Rosenthal, S. A., Kotcher, J. E., Marlon, J. R., Lyon, E., Goldberg, M. H. \& Maibach, E. W. (2019). Climate change in the American mind: data, tools, and trends. Environment: Science and Policy for Sustainable Development, 61, 4-18.

Berardo, R. \& Holm, F. (2018). The participation of core stakeholders in the design of, and challenges to, the US Clean Power Plan. Climate Policy, 18, 1152-1164.

Boussalis, C. \& Coan, T. G. (2016). Text-mining the signals of climate change doubt. Global Environmental Change, 36, 89-100.

Breetz, H., Mildenberger, M. \& Stokes, L. (2018). The political logics of clean energy transitions. Business and Politics, 20, 492-522.

Brulle, R. J. (2018). The climate lobby: a sectoral analysis of lobbying spending on climate change in the USA, 2000 to 2016. Climatic Change, 149, 289-303.

Brulle, R. J. (2019). Networks of opposition: a structural analysis of US climate change countermovement coalitions 1989-2015. Sociological Inquiry, 91(6), 1-22.

Carley, S., Evans, T. P. \& Konisky, D. M. (2018). Adaptation, culture, and the energy transition in American coal country. Energy Research \& Social Science, 37, 133-139.

Caughey, D., Xu,Y. \& Warshaw, C. (2017). Incremental democracy: the policy effects of partisan control of state government. The Journal of Politics, 79, 1342-1358. 


\section{Jiaqi Lu and Gregory Nemet}

Davis, C., Bollinger, L. A. \& Dijkema, G. P. (2016). The state of the states: data-driven analysis of the US Clean Power Plan. Renewable and Sustainable Energy Reviews, 60, 631-652.

Downie, C. (2017). Fighting for King Coal's crown: business actors in the US coal and utility industries. Global Environmental Politics, 17, 21-39.

Egli, F., Schmid, N. \& Schmidt, T. (2020). Electoral response to the decline of coal mining in the United States. Available at SSRN.

EIA (2019). More U.S. Coal-Fired Power Plants are Decommissioning as Retirements Continue [Online]. Available: www.eia.gov/todayinenergy/detail.php?id=40212\#.

EIA (2020a). Annual Coal Report [Online]. Available: www.eia.gov/coal/annual/.

EIA (2020b). Sales of Electricity to Ultimate Customers [Online]. Available: www.eia.gov/ electricity/monthly/epm_table_grapher.php?t=table_5_01

EIA (2021a). Average Price of Electricity to Ultimate Customers by End-Use Sector [Online]. Available: www.eia.gov/electricity/monthly/epm_table_grapher.php?t=epmt_5_6_a.

EIA (2021b). Capacity Factors for Utility Scale Generators Primarily Using Fossil Fuels [Online]. Available: www.eia.gov/electricity/monthly/epm_table_grapher.php?t= epmt_6_07_a.

Ellis, D. \& Fazeli, S. (2019). The 2019 U.S. Energy and Employment Report. Energy Futures Initiative and the National Association of State Energy Officials.

Farrell, J. (2016). Network structure and influence of the climate change countermovement. Nature Climate Change, 6, 370.

FERC (2018). Grid Reliability and Resilience Pricing, Order Terminating Rulemaking Proceeding, Initiating New Proceeding, and Establishing Additional Procedures.

Grumbach, J. M. (2018). From backwaters to major policymakers: Policy polarization in the states, 1970-2014. Perspectives on Politics, 16, 416-435.

Grumbach, J. M. (2019). Interest Group Activists and the Polarization of State Legislatures. Legislative Studies Quarterly, 45(1), 5-30.

Hermwille, L. \& Sanderink, L. (2019). Make fossil fuels great again? The Paris Agreement, Trump, and the US fossil fuel industry. Global Environmental Politics, 19, 45-62.

Jacques, P. J., Dunlap, R. E. \& Freeman, M. (2008). The organisation of denial: Conservative think tanks and environmental scepticism. Environmental politics, 17, 349-385.

Jakob, M., Flachsland, C., Steckel, J. C. \& Urpelainen, J. (2019).The political economy of climate and energy policy: A Theoretical Framework. EOPR General Conference, University of Wrocław, 4-7.

John, J. S. (2018). Legal Considerations for DOE's Leaked Coal and Nuclear Bailout Plan [Online]. Greentech Media. Available: www.greentechmedia.com/articles/read/ legal-doe-leaked-coal-and-nuclear-bailout-plan\#gs.amOEDRk.

Kang, K. (2016). Policy influence and private returns from lobbying in the energy sector. The Review of Economic Studies, 83, 269-305.

Karol, D. (2019). Red, Green, and Blue: The Partisan Divide on Environmental Issues, Cambridge University Press.

Layzer,J.A. (2012). Open for Business: Conservatives' Opposition to Environmental Regulation, MIT Press.

Lazard (2020). Levelized Cost of Energy and Levelized Cost of Storage Lazard Growth Acquisition Corp.

Lowry, W. R. (2008). Disentangling energy policy from environmental policy. Social Science Quarterly, 89, 1195-1211. 
Mccright, A. M. \& Dunlap, R. E. (2000). Challenging global warming as a social problem: an analysis of the conservative movement's counter-claims. Social problems, 47, 499-522.

Mccright, A. M., Xiao, C. \& Dunlap, R. E. (2014). Political polarization on support for government spending on environmental protection in the USA, 1974-2012. Social science research, 48, 251-260.

Morris, A. C., Kaufman, N. \& Doshi, S. (2019). The Risk of Fiscal Collapse in Coal-Reliant Communities. The Brookings Institution.

NCSL. (2020). State Renewable Portfolio Standards and Goals [Online]. National Conference of State Legislatures. Available: www.ncsl.org/research/energy/ renewable-portfolio-standards.aspx\#vi.

Podesta, J., Goldfuss, C., Higgins, T., Bhattacharyya, B., Yu, A. \& Costa, K. (2019). State Fact Sheet: A 100 Percent Clean Future [Online]. Center for American Progress. Available: www.americanprogress.org/issues/green/reports/2019/10/16/475863/ state-fact-sheet-100-percent-clean-future/.

Sivaram,V. (2018). The Dark side of Solar. The Brookings Institution.

Skocpol, T. \& Hertel-Fernandez, A. (2016). The Koch Network and Republican Party Extremism. Perspectives on Politics, 14, 681-699.

Stokes, L. C. \& Breetz, H. L. (2018). Politics in the US energy transition: case studies of solar, wind, biofuels and electric vehicles policy. Energy Policy, 113, 76-86.

Stokes, L. C. (2016). Electoral backlash against climate policy: a natural experiment on retrospective voting and local resistance to public policy. American Journal of Political Science, 60, 958-974.

Stokes, L. C. (2020). Short Circuiting Policy: Interest Groups and the Battle Over Clean Energy and Climate Policy in the American States, Oxford University Press.

The Ohio Legislature (2019). House Bill 6: Creates Ohio Clean Air Program.

The White House (2021). FACT SHEET: President Biden Takes Executive Actions to Tackle the Climate Crisis at Home and Abroad, Create Jobs, and Restore Scientific Integrity Across Federal Government.

Tyson A. \& Kennedy, B. (2020). Two-Thirds of Americans Think Government Should Do More on Climate [Online]. Pew Research Center. Available: www.pewresearch. org/science/2020/06/23/two-thirds-of-americans-think-government-should-domore-on-climate/

U. S. B. O. L. (2020). Coal Mining Employment. Available: https://data.bls.gov/timeser ies/CES1021210001.

Walton, R. \& Bade, G. (2018). FirstEnergy asks DOE for emergency action to save PJM coal, nuke plants. Utility Dive, March 29.

Wamsley, L. (2020). Ohio House speaker arrested in connection with $\$ 60$ million bribery scheme. NPR, July 21. 